\title{
Selection and Application of Fiscal and Tax Policy Tools for Army-civilian Integration
}

\section{Li Na}

Insititute for Finance and Economics, Central University of Finance and Economics, Beijing, China

\section{Email address:}

linanaxf@163.com

\section{To cite this article:}

Li Na. Selection and Application of Fiscal and Tax Policy Tools for Army-civilian Integration. International Journal of Accounting, Finance and Risk Management. Vol. 6, No. 1, 2021, pp. 1-9. doi: 10.11648/j.ijafrm.20210601.11

Received: December 23, 2020; Accepted: January 5, 2021; Published: January 12, 2021

\begin{abstract}
As a critical tool to optimize the allocation of resources, fiscal and tax policy plays an important role in promoting the deep development of army-civilian integration. This paper focuses on how to reasonably choose fiscal and tax policy tools to promote the development of army-civilian integration. First of all, it makes a comparative analysis of the decision-making body, scope, speed, cost and effect of all kind of fiscal and tax policy tools. Secondly, on the basis of combing the existing fiscal and tax policies, the paper points out the problems and shortcomings. The specific problem is the insufficient use of tool types and performance. The army-civilian integration of tools is not well targeted, and tools lack of pertinence for different types of army-civilian integration enterprises. Then, it further analyzes that the policy objectives, policy environment and the characteristics of army-civilian integration enterprises should be considered when selecting and optimizing fiscal and tax policy tools. Finally, on the foundation of the previous analysis, it gives suggestions on how to rationally choose and apply fiscal and tax policy tools to promote the further development of army-civilian integration. That is to say, when choosing fiscal and tax tools, on the one hand, we should not deviate from the performance of fiscal and tax policy tools, on the other hand, we should not ignore the development law of army-civilian integration industry. On this basis, we should strengthen the combination of fiscal policy tools and tax policy tools, the internal combination of tax policy tools and the internal combination of fiscal policy tools.
\end{abstract}

Keywords: Army-civilian Integration, Fiscal Policy Tools, Tax Policy Tools

\section{Introduction}

Fiscal and tax policies, as a tongs for the state to regulate the market, are the basic guidelines formulated by the state to guide fiscal distribution activities and deal with various fiscal distribution relations. They are also important policy means for the government to provide public goods, make up for "market failure" and promote stable economic development. They can not only play a positive role in the total economy, but also adjust the economy from the industrial structure through specific tools.

There are quite a few theoretical and empirical studies on fiscal and tax policy tools at home and abroad. Through the previous research, we can find that for different types of fiscal and tax policy tools, even the same type of internal specific fiscal and tax policy tools, there are different connotations, boundaries, advantages and disadvantages, and the legal requirements are not the same. The effectiveness of different policy instruments has distinct emphases. It is a problem to be solved in the process of deepening the army-civilian integration to study how to select the appropriate tool from multitudinous fiscal and tax tools. But up to now, the research in this area is relatively scarce. Most scholars only affirmed the important role of government intervention in army-civilian integration from the perspective of government. Zhao Fuyang [1] pointed out in his doctoral dissertation that the government's support for the innovation system of army-civilian integration is mainly realized through direct support and indirect support. An Jiakang and Chen Xiaohe [2] found that the higher the expected rate of return of military enterprises and private enterprises, the more they can promote cooperation and innovation. Therefore, it is suggested that in order to improve the expected rate of return of both sides, the government should give necessary subsidies and tax incentives to the units and enterprises participating in cooperative innovation, especially the civil units. Zhao Liming et al.[3] analyzed the evolutionary game behavior of army-civilian collaborative innovation, and concluded that 
when military enterprises and private enterprises evolve into the steady state of collaborative innovation, government subsidies are positively related to the steady state path of collaborative innovation. Xu Xiaomin and Wang Jin [4] pointed out that due to the main differences in tax support policies between civil enterprises and military enterprises, and the existing problems in policy implementation, the tax policy has not yet played an effective role in the field of army-civilian integration. Yao gong'an and Zhang Wenwen [5] analyzed and compared the tax contribution of enterprises before and after the army-civilian integration and the disadvantages of the current tax preferential policies through the model, and put forward some tax policy suggestions to promote the healthy development of the army-civilian integration. Based on the perspective of army-civilian integration, Yang Fan [6] combed the current situation of value-added tax exemption policy for military products, analyzed its main problems, and put forward relevant policy suggestions. Zhang Xi [7] summed up the main characteristics of the development and changes of financial support policies for the development of army-civilian integration in Liaoning Province on the basis of in-depth study of the financial support policies for the development of army-civilian integration in Liaoning Province. Kong Zhaojun et al. [8] constructed a dynamic panel model of the impact of government subsidies on the innovation investment of army-civilian integration enterprises, and found that government subsidies have a positive impact on the R\&D investment of army-civilian integration enterprises, and the local financial expenditure on science and technology can amplify the effect. Combined with the research conclusions and results of existing literature, this paper focuses on how to reasonably select fiscal and tax policy tools to promote the development of army-civilian integration. The research on this issue has certain theoretical and practical significance for the correct selection of appropriate fiscal and tax policy tools to promote the development of army-civilian integration.

\section{Performance Analysis of Fiscal and Tax Policy Tools}

From the principle of finance and taxation, fiscal and tax policy includes income and expenditure. Therefore, it can be roughly divided into tax policy (income policy tool) and fiscal policy (expenditure policy tool). The study starts from the two systems to carry out relevant research. The fiscal policy mentioned in the paper refers to expenditure policy, which usually includes purchasing expenditure (such as government direct investment), transfer expenditure (such as financial subsidies and financial discount), government procurement, policy guarantee expenditure and financial incentives; Generally speaking, revenue policy tools usually include tax, public loan, government funds and administrative fees, lottery public welfare fund and so on. The revenue policy in the study refer in particular to tax policy. Tax policy usually includes the levying and stopping of a certain tax, the setting of tax rate, tax reduction and tax penalty. There are many researches on the performance analysis of fiscal and tax policy tools, and most scholars make comparative analysis from two aspects: fiscal policy tools and tax policy tools. With regard to fiscal policy, the object of support is the specific fields and projects selected by the government, and whether to give support or not is in the hands of the government itself from the perspective of scope of action. It is more inclined to the prior incentive, whether it is financial subsidies or financial investment is the determine revenue from the perspective of the path of action. The effect of fiscal policy is more direct and rapid from the perspective of time effect. From the perspective of policy effect, fiscal expenditure directly affects the total social demand through multiplier effect, at the same time the policy strength is significant [9]. But the effect of fiscal policy may also decline, subsidy intervention will lead to crowding out effect and resource distortion allocation problems on the $\mathrm{R}$ $\& D$ expenditure of enterprises [10]. The crowding out effect is that financial subsidies will crowd out the R\&D expenditure of enterprises, and the distorted allocation of resources is shown in the effect evaluation of subsidies after the event according to the behavior of the recipients, so it will inevitably lead to selection deviation.

For the tax policy, from the perspective of the scope of action, as long as the enterprises that meet the tax preference standard can enjoy the tax preference, whether or not to enjoy the preferential policy is in the hands of the enterprise. From the perspective of action path, it belongs to post incentive, tax saving income is expected income, tax incentives can promote the increase of enterprise $R \& D$ investment, such as pre tax deduction of $R \& D$ expenditure, accelerated depreciation, preferential income tax, etc., which directly reduces the R\&D cost of enterprises, thus encouraging enterprises to increase R\&D expenditure [11]; Progressive income tax can reduce the gap between marginal private output and marginal social output and correct externalities. According to the army-civilian integration studied in this paper, tax can affect its development in three ways. The first is the production field. The resource allocation and direct investment behavior of army-civilian integration industry will be promoted or restricted by tax. For example, the adjustment of income tax will have a certain impact on the rate of return on investment, capital and the flow direction of investment of army-civilian integration enterprises. The turnover tax will affect the production, turnover amount or quantity of army-civilian integration products. Therefore, it will have a certain impact on the scale of production and investment in the field of army-civilian integration. Secondly, in the field of consumption, in theory, the taxation of certain products will lead to income effect and substitution effect. If the army-civilian integration products are tax-free or preferential, the cost of the relevant products will be reduced, and then there will be a certain substitution effect, which will bring about an increase in the demand for army-civilian integration products. The third is the field of distribution. By giving preferential tax treatment to the army-civilian integration, in fact, it has a certain impact on the distribution of interests of 
the vested interests of this part. When they feel that they will get more benefit distribution when they choose army-civilian integration, they will take the initiative to prefer the option with higher profits. From the perspective of time effect, it may take a long time for the effect of tax preferential policies to play. From the perspective of policy effect, the incentive effect of tax preference is better than that of financial subsidies in terms of market intervention, management cost and flexibility. Tax preferential policies tend to achieve long-term and stable effects through the optimal allocation of resources [12]. In addition, for different types of tax, the effect is also different. Turnover tax and income tax affect consumption demand through different ways. Turnover tax affects the structure of consumption demand by affecting the price of consumer goods, and the impact of income tax on consumption demand structure mainly comes from its adjustment of income and wealth distribution. besides, the income tax has a smaller inhibitory effect on the micro activities of enterprises, which is more suitable as a guiding tool for industrial development compared with the turnover tax [13]. However, we should also pay attention to the debt tax shield effect related to income tax, because the debt cost and equity cost will be deducted in different ways when the income tax is levied. The debt cost often enjoys certain pre tax deduction preference, so it will increase the scale of enterprise debt financing, and the expansion of debt scale will have an impact on the income of business activities.

Table 1. Comparison of financial support policies and preferential tax policies.

\begin{tabular}{lll}
\hline & Financial support policy & Preferential tax policies \\
\hline Scope of action & Specific areas and projects selected by the government & All enterprises that meet the preferential tax standards \\
Decision maker & Government choice & Independent decision making of enterprises \\
Action path & Pre incentive & Ex post incentive \\
Action speed & Direct and quick & Slower \\
Policy effect & Crowding out effect and distorted resource allocation & Fair, transparent, long-term effect is good \\
Policy cost & Higher & Lower \\
\hline
\end{tabular}

Table 2. The list of fiscal policy instruments in "Opinions on promoting the in-depth development of army-civilian integration of national defense science and technology industry".

\section{Policy intent \\ Support the development of private enterprises that undertake the key \\ tasks of military products and meet the government's investment policies \\ Expand investment and financing channels for army-civilian integration}

Fiscal policy tools

Investment in shares, subsidies, loan discount, leasing, borrowing and other ways to support

Set up national defense science and technology industry army-civilian integration industry investment fund
Generally speaking, the function of financial support policy is to guide enterprises to unfold relevant activities through the use of financial funds. For example, for army-civilian integration, more emphasis is placed on the transformation of scientific and technological achievements, and the tools used mainly include direct investment, subsidies, incentives, loan interest discount, etc.; while the preferential tax policy focuses on creating and optimizing the business environment of enterprises and stimulating enterprises and other microeconomics the main body develops activities. consequently, through the reasonable collocation of tax preferential policies and financial support policies, we can form a complementary policy framework that can effectively stimulate the development of enterprises, and is more conducive to the realization of national strategy.

\section{Application and Evaluation of Fiscal and Taxation Policy Tools for Army-civilian Integration}

\subsection{Current Situation of Fiscal and Taxation Policy Tools for Civil Military Integration}

In July 2016, the CPC Central Committee, the State Council and the Central Military Commission issued "opinions on the integrated development of economic construction and national defense construction", which contained very few contents of fiscal and tax incentive policies. From the perspective of the state, it only pointed out that the central and local financial departments should divide the responsibilities according to their responsibilities, implement the fund guarantee for army-civilian integration development, and improve the supporting policies. There is no mention of how to choose fiscal and tax policy tools. In December 2017, the general office of the State Council issued "opinions on promoting the in-depth development of army-civilian integration of national defense science and technology industry" (GBF [2017] No. 91). Compared with the opinion released in July 2016, it gives a relatively detailed description of which tools can be selected by fiscal policy to promote the development of army-civilian integration (Table 2), but the selection of tax policy tools is not involved.

Furthermore, in addition to these documents, the government departments have also issued some targeted documents, mainly aimed at "civilian military" enterprises, which are an important part of the implementation of the army-civilian integration strategy. For example, "guidance on further promoting the transfer of civilian technology to military" and "guidance on vigorously developing civil industry of national defense science and technology industry", these documents also mentioned the use of corresponding fiscal policy tools to promote the development of army-civilian integration. See Table 3 for details. 
Table 3. The list of relevant policies for "civilian military participation" enterprises.

\begin{tabular}{ll}
\hline File name & Document content \\
\hline "Guidance on further promoting the transfer of civilian & $\begin{array}{l}\text { Create a fair policy environment for civil technology and military. In terms of task competition, } \\
\text { investment and taxation, the units undertaking civil, technical and military tasks shall be given } \\
\text { equal policy treatment }\end{array}$ \\
$\begin{array}{l}\text { "Guiding opinions on vigorously developing national } \\
\text { defense science, technology, industry and civil industry" }\end{array}$ & $\begin{array}{l}\text { Strengthen the guidance of government investment and give full play to the role of tax policy } \\
\text { support and guidance }\end{array}$ \\
\hline
\end{tabular}

From the above analysis, it can be seen that at present, there are few documents related to fiscal and tax policies which are subordinate to the state level, and the provisions on the fiscal and tax policies are quite macro and not specific, which is of little significance to effectively push forward the development of army-civilian integration. In order to promote the development of local army-civilian integration, local governments have also implemented some fiscal and taxation policies, and basically formed a fiscal and taxation policy tool system with project subsidies, loan discount and project awards as the core, with Sichuan Province, Shaanxi Province and other military industrial provinces as the representative (Table 4). For the tax policy, although all localities have mentioned that certain tax preferences can be given to army-civilian integration enterprises, but in terms of the specific choice of preferential way, the local authority limit did not give a detailed plan.

\subsection{Evaluation of Fiscal and Taxation Policy Tools for Army-civilian Integration}

From the above analysis, we can obtain that China has adopted the relevant fiscal policy tools to promote the development of army-civilian integration industry, merely there are still numerous problems in the application process.

Table 4. The list of fiscal and tax policy tools in some provinces and cities.

\begin{tabular}{|c|c|c|c|}
\hline Province & Policy sources & Choice of fiscal policy tools & Choice of tax policy tools \\
\hline $\begin{array}{l}\text { Sichuan } \\
\text { Province }\end{array}$ & $\begin{array}{l}\text { "Fiscal and taxation policies and } \\
\text { measures to support scientific and } \\
\text { technological innovation and } \\
\text { industrial development of } \\
\text { army-civilian integration" }\end{array}$ & $\begin{array}{l}\text { Set up provincial army-civilian integration } \\
\text { industry development funds, project } \\
\text { subsidies, Project Awards, loan discount to } \\
\text { encourage bond financing }\end{array}$ & $\begin{array}{l}\text { The policy of additional deduction of R\&D expenses, } \\
\text { reduction and exemption of enterprise income tax on } \\
\text { technology transfer, reduction and exemption of real estate } \\
\text { tax and urban land use tax, and exemption of value-added } \\
\text { tax for military products produced by enterprises }\end{array}$ \\
\hline $\begin{array}{l}\text { Shanxi } \\
\text { Province }\end{array}$ & $\begin{array}{l}\text { The website of Shanxi Provincial } \\
\text { government }\end{array}$ & $\begin{array}{l}\text { Set up provincial army-civilian integration } \\
\text { special funds, project subsidies, financial } \\
\text { discount }\end{array}$ & $\begin{array}{l}\text { Reduction and exemption of military product value } \\
\text { added tax, land use tax and real estate tax }\end{array}$ \\
\hline $\begin{array}{l}\text { Hunan } \\
\text { Province }\end{array}$ & $\begin{array}{l}\text { The website of Hunan Provincial } \\
\text { government }\end{array}$ & $\begin{array}{l}\text { The establishment of provincial army-civilian } \\
\text { integration special fund, financing guarantee, } \\
\text { talent introduction subsidy, project subsidy, } \\
\text { project award, financial discount, personal } \\
\text { salary subsidy, etc }\end{array}$ & None \\
\hline $\begin{array}{l}\text { Hubei } \\
\text { Province }\end{array}$ & $\begin{array}{l}\text { The website of Hubei Provincial } \\
\text { government }\end{array}$ & Set up special funds and venture capital funds & None \\
\hline $\begin{array}{l}\text { Jiangxi } \\
\text { Province }\end{array}$ & $\begin{array}{l}\text { Army-civilian integration } \\
\text { (helicopter)'construction of } \\
\text { Jingdezhen base in Jiangxi Province }\end{array}$ & R\&D loans and subsidies & $\begin{array}{l}\text { Accelerated depreciation, land use tax paid before return, } \\
\text { plus deduction (preferential policy only for the } \\
\text { construction of Jingdezhen aviation industrial park) }\end{array}$ \\
\hline Beijing & $\begin{array}{l}\text { The website of Beijing } \\
\text { government }\end{array}$ & Financial incentives and housing subsidies & Tax preference (not specific) \\
\hline
\end{tabular}

\subsubsection{Shortage of Tool Type and Performance}

From the use of fiscal policy tools in the development of army-civilian integration mentioned above, it is not difficult to find that more tools are used for financial subsidies and incentives in the form of establishing special funds for army-civilian integration, but there are still some problems in the use of these tools. When used, it is simply proposed that subsidies and rewards can be given for army-civilian integration projects, but the forms of subsidies and rewards are not detailed. Subsidies can be divided into pre subsidy and post subsidy. The effects of the two kinds of subsidies may be quite different. Therefore, the appropriate form of subsidy should be selected according to the characteristics of the project; The forms of rewards can be divided into late stage rewards, performance awards, performance awards and so on. The incentive effects of each incentive form are also different. The general provisions give rewards to relevant army-civilian integration projects without subdividing them. Sometimes, instead of achieving the purpose of incentive, they may increase opportunistic behaviors, thus causing negative effects. As for other expenditure tools and tax tools, they are relatively less used. These tools also play an important role in promoting the development of army-civilian integration. For instance, government procurement is an organic combination of market competition mechanism and financial expenditure management. Through this tool, enterprises can obtain orders and increase sales. This kind of tool is especially suitable for encouraging the development of "civilian military" enterprises. Policy financing guarantee is also a kind of fiscal policy tool, but it is rarely used in promoting the development of army-civilian integration. At present, only Hunan Province mentioned in the policy measures "accelerate the in-depth development of civil military 
integration of national defense science and technology industry" (Development of Hunan Government Affairs Office [2018] No. 26) that the provincial reguarantee institutions can appropriately increase the proportion of reguarantee and compensation for the army-civilian integration of financing guarantee companies led by local governments. The policy tool is obviously insufficient in other provinces. In addition, the insufficient use of revenue policy tool tax policy is more obvious. Although local governments have mentioned in the relevant documents that they should give corresponding tax incentives to army-civilian integration enterprises, they are still limited in the ideas of tax preference and additional deduction. In fact, the final tax burden is not only affected by tax preference and additional deduction, but also by tax rate, tax basis, tax range and tax return, which will affect the level of tax burden and the effect of tax policy tools.

\subsubsection{The Army-civilian Integration of Tools Is Not Targeted}

Compared with the fiscal and tax policies supporting strategic emerging industries, high-tech industries and small and medium-sized enterprises, the fiscal and tax policies for promoting the development of army-civilian integration started late and is still in an exploratory stage, and is undergoing a process from fuzzy to clear, from unscientific to more scientific. However, looking at the application of the current fiscal and tax policies to promote the integration of military and civilian affairs, we can find that most of the fiscal and tax policies are only a simple translation to support other industries. For example, Sichuan Province, in implementing the preferential tax support policy, requires to seriously implement the national western development, high-tech enterprises, venture capital enterprises, and $\mathrm{R} \& \mathrm{D}$ expenses plus deduction. The tax support policies such as technology transfer income reduction, real estate and urban land use tax reduction and exemption have not given targeted tax preferential policies for army-civilian integration. Although there will inevitably be some generality in the choice of fiscal policy tools, any industry has its own characteristics and development rules. For example, army-civilian integration has its own characteristics in resources, technology, strategy, management, system and social level. Regardless of the industrial attributes and operation rules, it simply translates fiscal and taxation policy tools with experience imitation as the main tool instead of in-depth analysis of the essential performance of different industries. The result may be that the tool unification between industries is maintained in form, but it is difficult to promote effectively in essence. The development of army-civilian integration is not conducive to the realization of fiscal and tax policy tool effect.

\subsubsection{The Tool Lacks Pertinence to Different Types of Army-civilian Integration Enterprises}

The development of army-civilian integration is inseparable from the development of micro subject military civil integration enterprises. When it comes to army-civilian integration enterprises, from the perspective of chivalry, there are mainly two types of enterprises: one is "civilian participating in the military", that is, private enterprises. After obtaining military certification, they are qualified to participate in military supporting and provide the appropriate products of the company to the military; The other is "military to civilian" enterprises, that is, the military transfers military technology (non core technology) to private enterprises to promote technological innovation of enterprises. Actually, army-civilian integration enterprises do not only include these two types of enterprises. In addition to military industrial enterprises and public institutions and "military participating" private enterprises, they also include local colleges and research institutes engaged in army-civilian integration related research and personnel training, and even those enterprises (units) engaged in the research of emerging strategic industries and cutting-edge innovative technologies. In short, the scope of identification of army-civilian integration related enterprises is very wide, and it is not difficult to find that these different types of enterprises have their own suitable development models, and the problems they face in the process of development are also different. Therefore, there must be differences in the selection of fiscal policy tools to promote their development. For example, Gao Junmei [14] (2008) and others visited some private science and technology enterprises and found that non-public enterprises in our country entering the national defense military industry will face unfair treatment, poor information channels, financing difficulties, defects in government procurement methods, and mismatched macro management system. These problems are different from those faced by "military to civilian" enterprises. In the selection of fiscal policy tools, we should select the appropriate fiscal and tax policies according to the specific problems of "civilian participation in the army" enterprises. However, the current fiscal and tax policies do not make specific differences on this, only mention the use of corresponding fiscal policy tools to push forward the development of army-civilian integration.

\section{Factors Affecting the Choice of Fiscal and Taxation Policy Tools for Army-civilian Integration}

The selection of fiscal policy tools to promote the development of army-civilian integration will inevitably be affected by some factors. To a certain extent, these factors can be divided into two categories: subjective factors and objective factors, Among them, the former mainly comes from the preference and aversion of the ruling authorities for some fiscal and tax policy tools, and also has a certain relationship with the established interest pattern. Policy makers are often reluctant to break the established interest pattern when choosing fiscal and tax policy tools. The latter has many sources, which can be considered from the policy objectives, policy implementation environment and the characteristics of army-civilian integration.

In view of the subjective factors are mainly subject to the policy preferences of the ruling authorities, this will not be discussed here. The following mainly discusses the objective factors affecting the selection of fiscal policy tools for army-civilian integration. 


\subsection{Policy Objectives}

"The opinions on the integrated development of economic construction and national defense construction" clearly mentioned that the main task of the current army-civilian integration development is to form an all factor, multi field and high-efficiency development pattern of deep integration of civil and military affairs. This also determines that the target should be strictly followed when selecting fiscal and taxation policy tools, and no matter what policy tool is selected, it can not violate the goal. In fact, these are three objectives. In order to achieve each goal, the fiscal and tax policy tools to be selected may be different. For example, the total elements include the integration of technology, talents, resources, information and other elements. In order to promote the integration of technology, we can choose the form of financial subsidies and incentives, and for the integration of talents, we can choose the means of attracting talents and rewarding them to give relevant talents salary subsidies and income tax incentives. For the sake of integrate resources, we can give some preferential treatment to property tax and resource tax such as property tax and urban land use tax; In order to promote the integration of information, financial investment is needed to provide the corresponding public service platform. For this multi-objective form, we should keep appropriate dynamic when selecting policy tools. When a target form is achieved, we should adjust the current fiscal policy tools in time to ensure that they are consistent with the policy objectives.

\subsection{Tool Implementation Environment}

No matter what kind of fiscal policy tool is selected, it will fall on the evaluation of its operability and policy effect. Whether the instruments can be operated or not can't do without implementation environment. For example, the choice of fiscal instruments for expenditure is subject to the financial capacity of the central and local governments, which is simply the total amount of financial funds, because whether it is direct financial investment, financial subsidies or government procurement, to a certain extent, is limited by the total amount of financial funds. If the total amount of financial funds is insufficient, it determines that relying on direct financial support is far from enough to achieve policy objectives, which requires financial funds to play a leverage role to help enterprises broaden financing channels, and can choose to issue bonds, loan discount and financing guarantee tools. Revenue based policy tool-tax policy is mainly limited by the legislative authority of tax law, on account of the local government has no corresponding legislative power, so it will be subject to a great extent of restrictions in the selection of preferential forms.

Table 5. The list of characteristics and problems of different types of army-civilian integration Enterprises.

\begin{tabular}{lll}
\hline Type & Characteristic & Problem \\
\hline $\begin{array}{l}\text { Enterprise of } \\
\text { "Military to civilian" }\end{array}$ & $\begin{array}{l}\text { The military transfers military technology (non core } \\
\text { technology) to private enterprises to promote technological } \\
\text { innovation of enterprises }\end{array}$ & $\begin{array}{l}\text { It does not adapt to the market competition mechanism, and the } \\
\text { transformation of military technology mainly relies on the secondary } \\
\text { development of military industry units. The transformation channel is } \\
\text { single and the efficiency is insufficient. The existing incentive policies } \\
\text { are not workable }\end{array}$ \\
$\begin{array}{ll}\text { Enterprise of "people } \\
\text { joining the army" }\end{array}$ & $\begin{array}{l}\text { After military certification, they are qualified to participate } \\
\text { in military supporting and provide the company's } \\
\text { appropriate products to private enterprises for military use. } \\
\text { small scale, flexible system and difficult management }\end{array}$ & $\begin{array}{l}\text { Unfair treatment (unable to enjoy the same financial and tax } \\
\text { preferential treatment as state-owned military enterprises), poor } \\
\text { information channels, financing difficulties, defects in government } \\
\text { procurement methods, and inadequate macro management system }\end{array}$ \\
$\begin{array}{l}\text { Research and local } \\
\text { research institutes }\end{array}$ & $\begin{array}{l}\text { Institutions and non operational state-owned assets shall be } \\
\text { allocated by the financial department }\end{array}$ & \begin{tabular}{l} 
On the transformation of military research institutes into enterprises \\
\hline
\end{tabular}
\end{tabular}

\subsection{Characteristics of Army-civilian Integration Enterprises}

As mentioned above, there are different types of enterprises involved in army-civilian integration, including "military to civilian" enterprises, and "civilian participating in the military" enterprises. At the same time, it also includes some local colleges and research institutes engaged in research and personnel training related to army-civilian integration, and even enterprises (units) engaged in research on emerging strategic industries and cutting-edge innovative technologies. Each type of enterprise has its own characteristics and development law, which will inevitably affect the choice of corresponding fiscal and tax policy tools.

\section{Suggestions on the Choice of Fiscal Policy Tools for Army-civilian Integration}

To sum up, we conclude that there are still many deficiencies in the current fiscal policy tools in promoting the development of army-civilian integration. In addition, the selection of fiscal policy tools is also affected by some factors. In combination with these deficiencies and specific influencing factors, this paper gives some suggestions on how to choose the appropriate fiscal and tax policy tools.

\subsection{Fiscal and Tax Tools Are Used Equally}

From the analysis of the current use of fiscal and tax policy tools in China, we can see that they are more used than tax policy tools. However, the functions of adjusting income distribution, optimizing resource allocation and promoting technological progress are combined with tax policy tools. And combined with current value-added tax of China as the first big tax, and it has the advantage of tax neutral, so it is necessary to strengthen the use of tax policy tool. Owing to the limitation of tax legislative authority, the use of tax policy tools is greatly hindered. Therefore, it is necessary to establish corresponding tax policies for army-civilian integration from the national level. On the one hand, we can refer to the tax 
policies supporting high-tech industries, strategic emerging industries and small and medium-sized enterprises, but we can't blindly copy and translate. Corresponding policies should be formulated according to the respective characteristics of different types of army-civilian integration enterprises. For example, at present, most of the current general preferential policies in China tend to military enterprises, which is unfair to "army-civilian" enterprises. Therefore, in terms of tax preferential policies, we should increase the scope of preferential policies for "army-civilian" enterprises. We can give corresponding preferential policies in terms of value-added tax, income tax, land value-added tax, property tax and resource tax. Specifically, we can take two ways of tax reduction and exemption with low tax rate and tax base type deduction such as expanding the scope of tax exemption and increasing deduction items.

\subsection{Reasonable Selection of Tax Policy Tools}

In the selection of tax policy tools, we should take care two points. The first point is the interaction among various tax elements. The change of tax elements, such as tax subject, tax object, tax rate, tax basis and tax preference, will affect the effect of tax policy. Thus we should pay attention to the coordination among the elements. The second point is the combination between different kinds of configuration. The current tax system in China mainly includes four categories: turnover tax, income tax, property tax and behavior tax. Turnover tax is represented by value-added tax, consumption tax and customs duty. Income tax mainly includes enterprise income tax and personal income tax. Property tax is represented by property tax, and behavior tax mainly includes stamp tax and deed tax. In addition, there are taxes set up for specific purposes, such as land value added tax and urban maintenance and construction tax. The coordinated use of various taxes is very important to achieve the policy goal of promoting the development of army-civilian integration.

The coordination of internal elements of a single tax is crucial to the industrial layout, industrial status and investment pattern of the army-civilian integration. The tax subject decides who pays the tax, which also determines who owns the tax revenue, which will affect the implementation of the fiscal expenditure policy; the tax object directly defines whether to pay tax; the tax rate and tax basis directly determine the final amount of tax payable; tax preference plays a key role, which is the main factor in optimizing resource allocation, adjusting income and stimulating enterprise R\&D investment. Different forms of tax incentives have different incentive effects. As Shah [15] found that in order to effectively increase the $R \& D$ investment of enterprises, investment tax relief, credit and accelerated depreciation are more effective than the preferential forms of reducing corporate tax rate and deferred tax. For army-civilian integration enterprises, $R \& D$ investment is significant for the development of enterprises, so the preferential forms should be selected flexibly according to the characteristics of army-civilian integration enterprises. In addition, there are some differences in R\&D innovation between army-civilian integration industry and other industries. The biggest difference lies in the need for collaborative innovation. Zhao Liming and Chen Bingfu [16] have shown that for military enterprises and private enterprises, the income from collaborative innovation should be greater than that from independent R\&D. This shows that fiscal and tax policies should focus more on collaborative innovation rather than simply stimulating R\&D investment, which requires the government to select both positive and reverse incentives when selecting incentive tools. The so-called positive incentive is mainly applicable to those enterprises that actively carry out collaborative innovation, while for those enterprises that only wish to stay in independent $R \& D$, a certain negative incentive can be appropriately implemented, for example, this part of R\&D investment will not be deducted when calculating the corporate income tax.

The coordination of various taxes plays an important role in the development of different types of army-civilian integration enterprises. For the "military to civilian" enterprises, the foremost problems are institutional barriers and the transformation of military technology, which can not be effectively solved by tax policy tools alone. However, it faced by the "army-civilian" enterprises is that the threshold for joining the army is too high. Many "army-civilian" enterprises are excluded from the army-civilian integration enterprises due to they can not meet some rigid indicators. Consequently, when giving tax incentives, we should lower the entry threshold to a certain extent, so that some "civilian military" can also enjoy the relevant preferential treatment. Another problem they are facing is that the funds are insufficient and the enthusiasm for R\&D investment is not enough. Hence, for the enterprise income tax of "army-civilian participation" enterprises, more efforts can be made to deduct the R\&D investment. Besides, in order to encourage the marketization of the products of "civilian participating in the army" enterprises, the value-added tax of corresponding products should be directly reduced or exempted to some extent. In addition to the "military to civilian" and "civilian to military" enterprises, the relevant local colleges and research institutions play an important role in the development of army-civilian integration. Unlike enterprises, these institutions focus on the research and development of scientific and technological achievements and the cultivation of army-civilian integration talents. Then, the reduction and exemption of personal income tax and land use tax will play an important role in promoting its development. At present, military research institutes are faced with the problem of changing business to enterprise, which will lead to the use of tax preferences. The tax incentives for public institutions and enterprises are different. The problem to be solved by military research institutes to reform enterprises is to promote the marketization of military industry. The previous tax incentives for military research institutes will not affect its marketization development, so the previous preferential policies can be continued after the reform. In general, for military and civilian integration related enterprises generally involves some high value-added technical services consumer products, the 
proportion of intangible assets in the service and the product is higher, so the turnover tax incentive effect is not as income tax incentive effect is obvious. Therefore, on the one hand, we should pay attention to the cooperation of internal tax policy tools, and at the same time, we should also focus on the selection according to the characteristics of enterprises.

\subsection{Reasonable Combination of Fiscal Policy Tools}

The fiscal policy tool is also the expenditure policy tool. No matter which form is adopted, it will inevitably make some subjects enjoy extra benefits, which to a certain extent causes unfair phenomenon. Meanwhile, the expenditure of funds will also lead to regulatory problems. If the supervision is not in place, the unfair phenomenon will be magnified. These are the negative effects of the expenditure policy. However, as an important means for the state to intervene in the economy, the fiscal policy tool must have its positive side in making up for market failure and guiding the development of special industries. Generally speaking, there is no fault in the evaluation of tools themselves. The key is how to set a certain form through continuous innovation to avoid the spread of negative effects of tools, so that they can only show the positive effects they should show. For example, a certain upper limit standard can be set. In this regard, the practice of Sichuan Province is worth learning. In the financial and tax policies and measures to support the scientific and technological innovation and industrial development of army-civilian integration in Sichuan Province, the upper limit on the use of financial subsidies and financial incentives is stipulated. When supporting the R\&D of military technology to civilian use, it is stipulated that $10 \%$ of the R\&D investment will be subsidized from the provincial military civilian integration industry development fund, but the maximum amount is not more than 2 million yuan [17]. When financial rewards are given to major military civilian integration projects with an investment of more than 1 billion yuan (including 1 billion yuan) implemented by military and civilian integration enterprises in Sichuan Province, enterprises shall be given $2 \%$ of the investment amount from the provincial army-civilian integration industry development funds, but the maximum amount shall not exceed 10 million yuan.

In the light of the effect of fiscal policy tools, reasonable supervision and setting a certain upper limit can avoid the spread of its negative effects. But how to maximize its positive effects, we need to take note of two points. The first is to consider the combination of single fiscal policy tools. For instance, as mentioned above, financial support can be in a great deal of forms, such as prior support, after support, performance award and public welfare award, etc. Different forms of support have different effects. When choosing the form of support, we should combine the characteristics of the project itself to select flexibly. If necessary, two or more forms of support can be used at the same time. Another point that needs to be considered is the combination of different types of fiscal policy tools. After all, the scope of application of a single fiscal policy tool is limited. The combination of multiple fiscal policy tools can achieve the effect of $1+1>2$, which can be the most effective to a large extent, the incentive effect of fiscal policy tools can be realized, such as the combination of financial subsidies and loan discount, the combination of financial incentives and loan discount, the combination of financial direct investment and government procurement, etc. As one of the fiscal policy tools, the scope of government procurement is very limited. Combined with the characteristics of army-civilian integration, which integrates national defense construction and economic construction, the wide promotion of this policy tool should be of great benefit to the development of army-civilian integration.

Furthermore, for different types of army-civilian integration enterprises, even if they choose the same fiscal policy tools, they should operate flexibly according to the corresponding policy objectives. For example, the main problem of "military to civilian" enterprises at present is the system and mechanism, which leads to the lack of innovation vitality. Therefore, the government can use financial funds to guide the establishment of corresponding industrial investment funds, so as to diversify the investment and property rights entities, and increase the reorganization and integration efforts across groups and industries, thereby realize the system and mechanism that this type of enterprise fully integrates with the market economy. For "civilian military" enterprises, the establishment of industrial investment fund is mainly to solve the problem of insufficient funds, and its main goal is to expand financing channels. At present, the urgent problem facing scientific research institutes is how to realize the "reform of business to enterprise". Financial funds should play a guiding role, encourage diversified subjects such as industrial capital and venture capital to participate in the institutional restructuring, and help scientific research institutes establish a modern corporate governance structure.

Finally, the government should strengthen market research and research on the existing policy system before selecting fiscal and tax policy tools, so as to ensure that the new policy tools can achieve seamless convergence with existing tools, and try not to create new problems on the premise of solving existing problems. In addition, the selection of fiscal and tax policy tools is not immutable, but should be adjusted, modified, supplemented and updated in time according to the development of army-civilian integration. For example, in the initial stage of industry, direct tax preference and financial subsidies are more suitable for supporting industrial development. In the growth stage of industry, tax based indirect tax preference is more conducive to guide the rational allocation of resources, and the financial subsidies at this stage should focus on solving the difficulties of industrial development. In the mature stage of industrial development, the intervention degree of fiscal and tax policies should be reduced, and the free allocation of market should be brought into play. Finally, we should take care the role of fiscal and tax policy tools objectively and dialectically, and see their limitations. For example, although fiscal policy tools can promote the development of army-civilian integration and even guide more social capital to flow into the field of 
army-civilian integration, they also have inherent defects. On the one hand, the use of financial funds will increase the government's burden; on the other hand, it is easy to cause injustice due to uneven distribution of funds, and even corruption due to the excessive power of fund allocators. All in all, fiscal and tax policy tools are not the only tools to give impetus to the development of army-civilian integration, but also need to be used in combination with other policies.

\section{Conclusions}

In this paper, through the theoretical analysis of the performance of fiscal policy tools, combined with the problems in the current fiscal policy and comprehensive consideration of the factors that may affect the development of fiscal policy tools for army-civilian integration, the following conclusions are drawn.

First, although both financial support and tax preference can stimulate the development of army-civilian integration in theory, there are some differences between them in the scope of action, decision-making subject, action path, action speed, financial risk, policy cost and policy effect.

Second, although China has implemented corresponding fiscal and tax policies to promote the development of army-civilian integration, there are still some problems, such as the use of policy tools is not in-depth, the policy is not targeted and the characteristics of different types of army-civilian integration enterprises are not taken into account.

Third, China will be affected by a series of factors when choosing fiscal policy tools to promote the development of army-civilian integration, including policy objectives, policy implementation environment and industrial characteristics.

Fourth, how to choose the appropriate fiscal and tax policy tools should not be divorced from the performance of fiscal policy tools, nor ignore the development law of army-civilian integration industry. On this basis, we should strengthen the combination of fiscal policy tools and tax policy tools, the internal combination of tax policy tools and fiscal policy tools.

\section{References}

[1] Zhao Fuyang. Research on the innovation system of army-civilian integration in defense science and technology industry of China [D]. Harbin: Harbin Engineering University, 2010.

[2] An Jiakang, Chen Xiaohe. Evolutionary game analysis and countermeasure research on cooperation mechanism of technological innovation-Based on the perspective of army-civilian cooperation [J]. Economic Issue, 2012 (5): 65-69.
[3] Zhao liming, Sun Jianhui and Zhang Haibo. Analysis on collaborative innovation behavior of army-civilian integration technology [J]. Scientific and Technological Progress and Countermeasures, 2015, 32 (13): 111-117.

[4] Xu Xiaomin and Wang Jin. Policy issues and reform suggestions of military products exempt from VAT-Based on the perspective of army-civilian integration development [J]. Tax Research, 2019 (08): 98-102.

[5] Yao gong'an and Zhang Wenwen. Research on tax support strategy of enterprises participating in army-civilian integration [J]. China Science and Technology Forum, 2019 (06): 99-104.

[6] Yang Fan. Giving full play to the positive role of Taxation to promote the further development of army-civilian integration [J]. Macroeconomic Management, 2019 (02): 79-83.

[7] Zhang Xi. A preliminary study on the financial support policy for the development of army-civilian integration in Liaoning Province [J]. Liaoning Economy, 2019 (10): 56-57.

[8] Kong Zhaojun and Zhang Yumeng. The impact of government subsidies on the innovation of army-civilian integration Enterprises [J]. Scientific and Technological Progress and Countermeasures, 2020.

[9] Guellec, D. \& B. V. Pottelsberghe. The Impact of Public R \& D Expenditure on Business R\&D [J]. Economics of Innovation \& New Technology, 2003, 12 (3): 225-2430.

[10] N Shah. Fiscal and tax incentives to promote investment and innovation [M]. Economic Science Press, 2000.

[11] Chen $\mathrm{Yu}, \mathrm{Fu}$ Lin. The orientation of fiscal and taxation policies for the upgrading of China's industrial structure [J], Tax Research, 2015 (4): 22-26.

[12] Gao Junmei, Tian Dashan, Li Xiaoning. Government policy and management of civilian participation in the army $[\mathrm{J}]$. Chinese Military to Civilian, 2008.8.

[13] Jiang Jing. The performance of public policy supporting enterprise innovation: a comparative analysis based on direct subsidy and tax preference $[\mathrm{J}]$, Scientific Research Management, 2011 (4): 1-8+50.

[14] Lu Daozhen, Yu Fei, Xia Nan, et al. Research on the reform and development mode of scientific research institutes in the civil military integration system [J]. Chinese Military to Civilian, 2018 (8): 18-24.

[15] Tao Chun, Zhang Nannan and An mengchang. Dual Use Technologies and Products [J]. 2014 (12): 11-13.

[16] Zhang Haixing, Liu Dequan. The choice of fiscal policy for the optimization and upgrading of industrial structure during the 12th Five Year Plan Period [J]. Business Research, 2011 (10): $1-7$.

[17] Zhao Guoqin, Gao Fei. The choice of fiscal and tax policies to guide industrial development: Based on the panel data of listed companies [J]. Tax Research, 2016 (10): 22-27. 